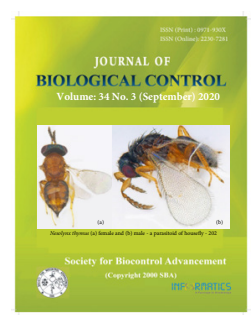

\title{
Kin recognition by the adults of a biological control agent, Propylea dissecta (Coleoptera: Coccinellidae)
}

\author{
AHMAD PERVEZ ${ }^{*}$ and MOINA KHAN \\ Biocontrol Laboratory, Department of Zoology, Radhey Hari Govt. P.G. College, Kashipur, U.S. Nagar-244713 (Uttarakhand), \\ India \\ *Corresponding author E-mail: ahmadpervez@yahoo.com
}

\begin{abstract}
The ability to recognize kin is a well-established behavior across several animal phyla including insects. A laboratory experiment was designed to find out whether adults of an aphid-biocontrol agent, Propylea dissecta (Coleoptera: Coccinellidae) may avoid consuming their own eggs in prey scarcity in the presence of unrelated conspecific eggs. For the purpose, starved parent ladybirds were provided with their eggs and unrelated conspecific (alien) eggs in the absence of their natural prey (aphids). The predatory/ avoidance behavior of the parents towards alien-eggs and their eggs was recorded. The adult male of $P$. dissecta had lesser food demand than the female and consumed significantly lesser $(0.7 \pm 0.20) \mathrm{kin}$ eggs than the alien eggs (2.8 \pm 1.89$)$. Similarly, the adult female cannibalized significantly lesser number of kin eggs $(1.6 \pm 0.209)$ than the alien-eggs (3.5 \pm 0.15$)$. Seemingly, both the parents had recognized their eggs and refrained from consuming them. This could be a strategy adopted by the parents to conserve their gene-pool and to further protect it by consuming the heterospecific eggs of potential enemies (alien eggs) in prey scarcity. This insurance of their gene-pool could benefit these parents by conserving their genetic lines.
\end{abstract}

KEY WORDS: Egg cannibalism, kin recognition, Propylea dissecta

(Article chronicle: Received: 01-09-2020; Revised: 27-09-2020; Accepted: 29-09-2020)

Kin recognition is the process of assessing genetic relatedness using certain cues and preferentially providing benefits to the relatives (Schausberger, 2007; Bos et al., 2011). Several behavioral patterns like colonization plans, mating, cannibalism, defense, etc. are probably influenced by this ability. This behavior is seemingly triggered through the chemical label(s) on the body and a template in the brain of an individual. Chemical cues in the form of colony specific odours are known to exist among social insects, such as ants and bees (Bos et al., 2011). Kin-recognition is advantageous, as it provides numerous benefits, viz. resource exploitation, sex allocation, avoidance of kin cannibalism and avoidance of inbreeding depression (Fellowes, 1998; Saxena et al., 2016, 2018). Thus, an individual may increase its inclusive fitness and aid to ensure the survival of a specific gene group increasing genetic representation of a species. For the augmentation of predatory insects, particularly biocontrol agents, this aspect of kin recognition may be exploited in augmentative rearing and to utilize them as biological control agents against numerous phytophagous insect pests (Omkar and Pervez, 2016).
Propylea dissecta (Mulsant) (Coleoptera: Coccinellidae) is an aphidophagous ladybird from the Oriental region, which preys upon numerous aphid species (Pervez and Omkar, 2004, 2005; Pervez and Kumar, 2017) and has immense aphid-biocontrol potential (Pervez and Omkar, 2011). Endogenous cues, like relatedness, seem to be the driving force for the avoidance of cannibalizing inferior and immature conspecifics (Joseph et al., 1999; Pervez et al., 2005). The success of this species in the Oriental region may depend on its ability to recognize its kin. The Kin recognition in this species was thus tested among the adults to find out whether males could also recognize the eggs and deter to cannibalize them. Keeping in view, we attempted to address the question, whether both the adult parents recognize their offspring and avoid consuming them in prey scarcity.

\section{Maintenance of stock culture}

Adults of P. dissecta were collected from cowpea (Dolichos lablab L.) fields near the suburbs of Kashipur, India $\left(29.2104^{\circ} \mathrm{N}, 78.9619^{\circ} \mathrm{E}\right)$ preying on aphid, Aphis craccivora (Koch). These adults were brought to the laboratory and 
paired in plastic Petri dishes $(9.0 \mathrm{~cm}$ diameter $\times 2.0 \mathrm{~cm}$ height $)$ containing ad libitum supply of above aphid. Thereafter, the Petri dishes were kept in the Environmental Test Chamber (ETS) (REMI, Remi Instruments) maintained at $27 \pm 2{ }^{\circ} \mathrm{C}$; $65 \pm 5 \% \mathrm{RH}$; 14L: 10D. The adults mated and females laid eggs in batches (two batches of 20-35 eggs per day). The $\mathrm{F}_{1}$ eggs, thus obtained were carefully isolated in separate Petri dishes (size as above) and reared till adult emergence (size and prey as above). Thus, the $\mathrm{F}_{1}$ adult males and females obtained were paired in separate Petri dishes (size and prey as above) to obtained $\mathrm{F}_{2}$ eggs to be used in the experiment. The eggs obtained from the same parents were designated as kin eggs, while the eggs from a different parental line were designated as alien eggs. We used only kin and alien eggs as the experimental models and not the larval instars, as the parents were more prone to recognize their own odours on the egg surfaces than those on the larval instars.

\section{Experimental design}

The experiment was aimed to investigate whether parents can recognize their eggs and avoid eating them in starvation. For the purpose, 10-day-old adult male and female $P$. dissecta were separately exposed to their own and alien eggs (which obtained from another conspecific female) in the absence of their regular food, i. e. aphids. The alien eggs were the eggs obtained from different conspecific parents that were reared in parallel with other parental line. The surface odours on the kin and alien eggs may differ due to difference in the parental lines collected from the same field. Ten own- eggs were arranged in a row at a distance of $0.35 \mathrm{~cm}$ from the centre of a Petri dish $(9.0 \times 2.0 \mathrm{~cm})$. A second parallel row of eggs from different parents was made in the Petri dish at a distance of $0.7 \mathrm{~cm}$ from the own-egg row. We made two experimental treatment by arranging kin and alien eggs and introduced a 12- hour starved (i) adult male and (ii) female ladybirds separately in each Petri dish. The adult (male or female) ladybird was released in the centre of the Petri dish (from where it was equidistant to both kinds of eggs) and its cannibalizing behavior was observed and the number of own eggs and alien-eggs consumed by it was carefully recorded for three consecutive hours. The experiment was replicated ten times $(\mathrm{n}=10)$. The data on the number of eggs consumed was subjected to a non-parametric Wilcoxon Signed Rank Test using the statistical software SAS (2002) on the personal computer. The effect of 'gender' and 'kinship' on kin recognition was analyzed using two-way ANOVA with cannibal 'gender' (two levels) and 'kinship' (two levels) as independent variables and number of eggs cannibalized as dependent variable (SAS, 2002).

The results revealed that the adult male consumed significantly lesser number of eggs sired by him $(0.7 \pm 0.202)$ than the alien eggs $(2.8 \pm 1.89)(\mathrm{Z}=-3.7112 ; \mathrm{P}<0.0001 ; \mathrm{d}$. f. $=$ 1) (Fig. 1). Similarly, the adult female consumed significantly $(\mathrm{Z}=-3.7742$; $\mathrm{P}<0.0001$; d. $\mathrm{f} .=1)$ lesser number of eggs that were laid by her $(1.6 \pm 0.209)$ as compared to alien eggs (3.5 \pm 0.158$)$. Seemingly, the female had a relatively lower food demand. Two-way ANOVA revealed a significant main effect of "gender" $(\mathrm{F}=15.78 ; \mathrm{P}=0.0003$; d. f. $=1)$ and "kinship" ( $\mathrm{F}=98.63 ; \mathrm{P}=0.0001 ;$ d. f. $=1)$. The interaction between "gender" and "kinship", however was not found to be statistically significant $(\mathrm{F}=0.25 ; \mathrm{P}=0.6225 ; \mathrm{d}$. $\mathrm{f} .=1)$. The data were pooled to quantify the significant difference

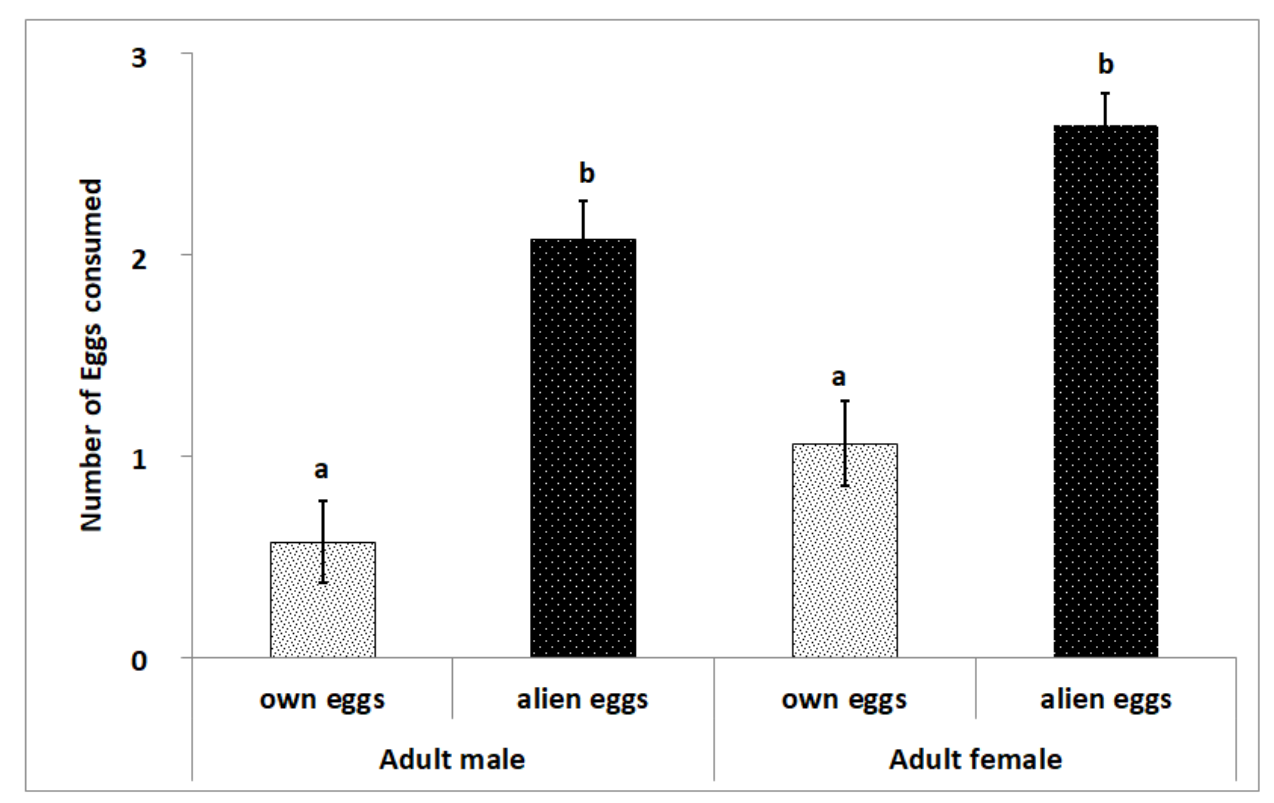

Fig. 1. Number of eggs consumed by adult male and female, $P$. dissecta when provided with own eggs and alien eggs. Error bars revealed S.E. Different letters show that the data is statistically significant at $\mathbf{P}<0.0001$ 
between the overall consumption of own eggs and alien eggs. Overall, the data on the consumption of own eggs and alien eggs were found to be statistically significant $(\mathrm{F}=38.22$; $\mathrm{P}<0.0001$; df 3, 39).

Food demand in the female is probably higher due to high metabolic needs for oviposition. Initially, female ladybird was more reluctant to eat its eggs but as the natural prey, i.e. aphid, was absent, she resorted to cannibalism. This initial reluctance to cannibalism could be because every species supports the sustenance of its genes to the next generation. Thus, avoiding kin-cannibalism can benefit an individual species to increase its genetic fitness. Marked reluctance showed by female beetles to eat their eggs and larvae to eat sibling eggs is likely to reduce the incidence of kin cannibalism under natural conditions (Agarwala and Dixon, 1993). Female tends to recognize her eggs due to the presence of surface alkanes on them (Omkar et al., 2004; Pattanayak et al., 2014, 2016). Bayoumy and Michaud (2015) found that females of Hippodamia convergens GuerinMeneville recognized their egg clusters and preferred to consume nonfilial egg clusters. Adult females of $P$. dissecta and Coccinella transversalis (Fabricius) showed a strong reluctance to cannibalize sibling eggs during the first few encounters, during the first hour of exposure (Pervez and Chandra, 2018). Seemingly, the quantitative differences in the surface or cuticular hydrocarbons play a major role in the kin-recognition (Lihoreau and Rivault, 2009). Cannibalism of unrelated conspecific eggs is considered advantageous for the expedited development and increased survival prospects in the ladybirds (Roy et al., 2007). Kin-recognition and avoidance of kin cannibalism was evident at the larval level in ladybird species, $P$. dissecta and C. transversalis (Pervez et al. 2005).

Agarwala and Dixon (1993) reported that females of Adalia bipunctata (Linn.) can recognize kin, however, males do not. However, we found that even male ladybird could recognize the eggs he sired by refraining from consuming them. Consumption of significantly greater number of alien eggs than the eggs he sired clearly indicate that male ladybird is also recognizing his eggs. This might be due to the presence of his own chemical signature on the eggs or that of her female, which tends to make him differentiate between the two types of eggs offered and avoid to consume the eggs he sired. Little is known on this aspect, previously it assumed that male insects exhibit no attachment towards the eggs sired by them (Agarwala and Dixon, 1993). More research is needed to better understand the cues responsible for the kin-recognition of eggs by the male ladybird. The knowledge on how adultladybirds approach towards kin or non-kin eggs during prey scarcity for their own species survival and subsistence may help in the aphid-biocontrol prospects of the adult ladybirds along with their confinement in the prey habitats in patchy prey conditions.

\section{ACKNOWLEDGEMENT}

The first author is thankful to the Science and Engineering Research Board, Department of Science and Technology, Government of India for funding in the form of Major Research Project (EMR/2016/006296).

\section{REFERENCES}

Agarwala BK, Dixon AFG. 1993. Kin recognition: egg and larval cannibalism in Adalia bipunctata (Coleoptera: Coccinellidae). Eur. J. Entomol. 90: 45-50.

Bayoumy MH, Michaud JP. 2015. Egg cannibalism and its life history consequences vary with life stage, sex, and reproductive status in Hippodamia convergens (Coleoptera: Coccinellidae). J. Econ. Entomol. 108(4): 1665-1674. https://doi.org/ 10.1093/jee/tov148.

Bos N, Grinsted L, Holman L. 2011. Wax on, wax off: nest soil facilitates indirect transfer of recognition cues between ant nestmates. PLoS ONE 6: e19435 (doi:10.1371/ journal. pone. 0019435.t001).

Fellowes MDE. 1998. Do non-social insects get the (kin) recognition they deserve? Ecol. Entomol. 23: 223-227. https://doi.org/10.1046/j.1365-2311.1998.00128.x

Joseph SB, Snyder WE, Moore AJ. 1999. Cannibalizing Harmonia axyridis (Coleoptera: Coccinellidae) larvae use endogenous cues to avoid eating relatives. J. Evol. Biol. 12: 792-797. https://doi.org/10.1046/j.14209101.1999.00077.x

Lihoreau M, Rivault C. 2009. Kin recognition via cuticular hydrocarbons shapes cockroach social life. Behav. Ecol. 20(1): 46-53. https://doi.org/10.1093/beheco/arn113.

Omkar, Pervez A, Gupta AK. 2004. Role of chemicals in egg cannibalism and intraguild predation by neonates of two generalist ladybirds, Propylea dissecta and Coccinella transversalis. J. Appl. Ent. 128 (9-10): 691-695. https:// doi.org/10.1111/j.1439-0418.2004.00913.x

Omkar, Pervez A. 2016. Ladybird Beetles. pp. 281-310. In: Omkar (ed.). Ecofriendly Pest Management for Food Security. Academic Press. London, UK. https://doi. org/10.1016/B978-0-12-803265-7.00009-9

Pattanayak R, Mishra G, Chanotiya CS, Rout PK, Mohanty CS, Omkar. 2016. Semiochemical profile of four aphidophagous Indian ladybird beetles. Can. Ent. 148: 171-186. https://doi.org/10.4039/tce.2015.45 
Kin recognition by the adults of a biological control agent, Propylea dissecta

Pattanayak R, Mishra G, Omkar, Chanotiya CS, Rout PK, Mohanty CS. 2014. Does the volatile hydrocarbon profile differ between the: a case study on five aphidophagous ladybirds? Arch. Ins. Biochem. Physiol. 87: 105-125. https://doi.org/10.1002/arch.21184

Pervez A, Chandra S. 2018. Incidence of Egg-cannibalism by stage specific kins of two predaceous ladybirds (Coleoptera: Coccinellidae). J. Mountain Res. 13: $45-50$.

Pervez A, Gupta AK, Omkar. 2005. Kin recognition and avoidance of kin cannibalism in aphidophagous ladybirds: a laboratory study. Eur. J. Entomol. 102(3): 513-518. https://doi.org/10.14411/eje.2005.073

Pervez A, Kumar R. 2017. Preference of the aphidophagous ladybird, Propylea dissecta for two species of aphids reared on toxic host plants. Eur. J. Environ. Sci. 7(2): 130-134. https://doi.org/10.14712/23361964. 2017.12

Pervez A, Omkar. 2004. Prey Dependent Life Attributes of an Aphidophagous Ladybird Beetle, Propylea dissecta (Mulsant). Biocontrol Sci. Technol. 14(4): 385-396. https://doi.org/10.1080/09583150410001683547

Pervez A, Omkar. 2005. Functional response of coccinellid predators: An illustration of a logistic approach. J. Insect Sci. 5(5): p.1-6. https://doi.org/10.1673/031.005.0501
Pervez A, Omkar. 2011. Ecology of an aphidophagous ladybird Propylea: A Review. J. Asia Pacific Entomol. 14(3): 357-365. https://doi.org/10.1016/ j.aspen.2011.01.001

Roy HE, Rudge H, Goldrick L, Hawkins D. 2007. Eat or be eaten: prevalence and impact of egg cannibalism on two-spot ladybirds, Adalia bipunctata. Entomologia experimentalis et Applicata 125(1): 33-38. https://doi. org/10.1111/j.1570-7458.2007.00592.x

SAS, 9.0 2002. SAS/Stat Version 9, SAS Institute Inc., Cary, NC, USA.

Saxena, S, Mishra G, Omkar. 2016. Inbreeding avoidance in aphidophagous ladybird beetles: a case study in Cheilomenes sexmaculata. Can. J. Zool. 94: 361-365. https://doi.org/10.1139/cjz-2015-0174

Saxena S, Mishra G, Omkar. 2018. Familiarity dominates relatedness in mate selection in ladybirds. J. Zool. 304: 55-64. https://doi.org/10.1111/jzo.12497

Schausberger P. 2007. Kin recognition by juvenile predatory mites: prior association or phenotype matching? Behav Ecol Sociobiol. 62: 119-125. https://doi.org/10.1007/ s00265-007-0444-9 